\title{
Agents of Change: How Islamist Women Activists in Israel Are Challenging the Status Quo
}

\author{
Tilde Rosmer \\ Department of Culture Studies and Oriental Languages, University of Oslo and \\ Zayed University, United Arab Emirates \\ tilderosmer@yahoo.no
}

\begin{abstract}
From the public profile and media reporting on the Islamic Movement in Israel (al-Haraka al-islämiyya fí Isrā'ill), the impression given is that this movement is run by men, and that women are, if visible, in the background. However, when looking behind the façade it becomes clear that women are not only active, but are at the forefront of Islamist activism, spearheading change in their community. In their organizations for women, and through informal channels, they educate women, and indirectly men, about the role and position of women in Islam. Their activism also contributes to creating awareness about their Palestinian Arab Muslim history and predicament, thus also empowering women vis-à-vis Israeli domination. The women interviewed for this article all studied or study at Israeli universities, and as educated women they are reshaping the ideal of the traditional Muslim mother into that of a Muslim professional working mother. Based on the logic behind and content of their Islamist activism, the present article argues that these women are agents of change who contest the traditional ideal and practical role of Muslim Palestinian women in Israel. They are challenging patriarchal traditions and domination in their community through their Islamist activism; however, this frame simultaneously produces limitations to their opposition.
\end{abstract}

\section{Keywords}

Islamist activism - Israel - Islamic Movement in Israel - female student activists Palestinian citizens of Israel - segregation - patriarchy 


\section{Introduction}

Although a small but growing body of literature has studied the Islamic Movement in Israel (al-Haraka al-islämiyya fì Isrā'sl), ${ }^{1}$ there is still very little scholarship about the movement's female activists. ${ }^{2}$ Based on fieldwork material from 2008-13, this article contributes to fill this lacuna. Based in particular on in-depth interviews with one female pioneer and six female student activists from the Islamic Movement in Israel, it also relies on a survey conducted by the researcher among 53 students, of whom 32 were female. In addition, it draws on interviews with numerous other activists and leaders of the movement, including male students, as well as written and web-based material by the movement, supplemented with secondary sources and Israeli Hebrew media. ${ }^{3}$

1 The most significant works include Issam Aburaiya, "The 1996 Split of the Islamic Movement in Israel: Between the Holy Text and Israeli-Palestinian Context", International Journal of Politics, Culture, and Society 17, no.3 (2004), 439-55, doi:10.1023/B:IJPS.0oooo19612.42870.6d; Muhammad Hasan Amara, "The Nature of Islamic Fundamentalism in Israel", Terrorism and Political Violence 8, no.2 (1996), 155-70, doi:10.1080/09546559608427351; Michael Dumper and Craig Larkin, "In Defence of Al-Aqsa: The Islamic Movement inside Israel and Battle for Jerusalem”, Middle East Journal 66, no.1 (2012), 31-52, doi:10.3751/66.1.12; Alisa Rubin Peled, Debating Islam in the Jewish State: The Development of Policy Toward Islamic Institutions in Israel (New York: State University of New York Press, 2001); Raphael Israeli, "The Islamic Movement in Israel",Jerusalem Letter,Jerusalem Centre for Public Affairs no. 416 (1999)<http:// www.jcpa.org/jl/jl $146 . h t m>$; Elie Rekhess, "The Islamic Movement in Israel: The Internal Debate over Representation in the Knesset", Proceedings of a Lecture at Conference Between Jihad and Peace - Islamist Alignments in a Changing Middle East, Moshe Dayan Center, (Tel Aviv University, 1996); Tilde Rosmer, “Resisting 'Israelization': The Islamic Movement in Israel and the Realization of Islamization, Palestinization and Arabization", Journal of Islamic Studies 23, no.3 (2012), 325-58, doi:10.1093/jis/etso54; Tilde Rosmer, "The Islamic Movement in the Jewish State", in Political Islam: Context versus Ideology, ed. Khaled Hroub (London: Saqi, in association with London Middle East Institute, sOAs, 2010); Tilde Rosmer, "Raising the Green Banner: Islamist Student Politics in Israel", Journal of Palestine Studies 45, no.1 (2015), 24-42 doi:10.1525/jps.2015·45.1.24.

2 Marion Boulby, "Women and the 'Islamic Movement' in Israel: Challenge to Patriarchy?", Historical Reflections / Réflexions Historiques 30, no.3 (2004), 491-507 <http://www.jstor.org/ stable/41299320>; and Inbal Tal, Spreading the Movement's Message: Women's Activism in the Islamic Movement in Israel (in Hebrew) (Tel Aviv: Moshe Dayan Center and Konrad Adenauer Stiftung, 2016).

3 The fieldwork consists of one month in July 2008, January-May 2009, two weeks in May 2010, two weeks in November 2010, meetings with representatives of the Northern branch in London August 2011, two weeks in January 2012 and one week in November 2013. 
Patriarchy is a social arrangement of society and family that privileges men over women and old over young. Abu-Lughod's groundbreaking analysis of how Bedouin women in Egypt felt ambivalent and acted simultaneously in support of and in opposition to the patriarchal system that governed their lives, exposed the complexity of moral systems and lived culture. ${ }^{4}$ This perspective has inspired Roald's study of how Palestinian women in the occupied West Bank on a macro level maintain "benevolent patriarchy" - the power of the "good", "self-sacrificing", and "loving" patriarchal man - and simultaneously resist this very system of power through their actions on a micro level. ${ }^{5}$ The predicament of Muslim Palestinian women inside Israel is different from the situation in the West Bank due to the sociopolitical context, but the tension created by concurrently upholding traditional patterns with a patriarchal base and challenging social limitations imposed on women, is similar. The perspective of Ahmed, which analyses veiling and gender segregation in Egypt in the 1970s as "charged with other issues - culture and nationalism, 'Western' versus 'indigenous' or 'authentic' values", captures the multilayered explanation for the continuation of this practice among Palestinians in Israel, who simultaneously are tackling what they see as the threat of Israelization and patriarchal Islamic traditions. ${ }^{6}$ Using this approach, this article focuses on how a small group of young female Islamist activists use precisely their Islamic world view and religiously inspired activism to critique and challenge patriarchal practices to shape a new Muslim Palestinian Arab woman model in Israel.

\section{The Interviewees}

The present analysis is a result of reanalysing interview transcripts from 2008 until 2013, looking at how these interviewees spoke about being women and their struggles against patriarchal domination. To clarify, they were not asked about patriarchy or their views on gender roles or relations, but they chose to talk about this aspect when answering broader questions about their activism. As such, there were no gender-specific questions asked, unless the conversation led to such topics, in which case these were impulsive follow-up questions. The interviews were semi-structured, beginning with a biographical introduction followed by open questions, such as "How did you become active

4 Lila Abu-Lughod, Veiled Sentiments:Honor and Poetry in a Bedouin Society (Berkeley:University of California Press, 1986).

5 Anne Sofie Roald, "'Benevolent Patriarchy': Palestinian Women between 'Ideal' and 'Reality", Islam and Christian-Muslim Relations 24, no.3 (2013), 334, doi:10.1080/09596410.2013.788275.

6 Leila Ahmed, A Quiet Revolution: The Veil's Resurgence, from the Middle East to America (New Haven, London: Yale University Press, 2011), 130. 
in the Islamic Movement?", "What is your role in the Islamic (student) Movement?", and "What are the ideological and practical goals of the movement in your understanding?". Thus this analysis can be described as a bottom-up representation of the reflections on their engagement in Islamic activism, their views on the role and position of women in Islam, their future as educated professional women, and the practical conduct of segregated Islamic activism at universities in Israel.

All the interviews were conducted on the university campus, in the university dorms, or in the Islamic Movement offices elsewhere, and all interviews were recorded. The students were interviewed with the assistance of an interpreter in Arabic, while the pioneer was interviewed in Hebrew by the researcher. All student activists are anonymized, but individuals in formal positions are identified according to their wish. The students were all in their early twenties and unmarried, while the pioneer was in her late forties, married with children and grandchildren.

It is important to note that while many Palestinian women in Israel today attend higher education institutions, the positions and perceptions of these relatively privileged middle-class students do not represent all Muslim women in Israel. ${ }^{7}$ As such, these interviewees can be described as "elite", which, as noted by Ashfar, is of importance for the analysis. ${ }^{8}$ The interviews were conducted at the University of Haifa, Tel Aviv University, and the Hebrew University in Jerusalem, and all of the students interviewed come from the north and centre of Israel. As young women living far away from their families and communities in dormitories with Israeli Jewish students, and having, as they presented it, chosen their own areas of study, they all exhibited agency and ownership over not only their thoughts and ideas but also their life choices so far.

As with the study of anything pertaining to Palestinians in Israel, the issue of women's position and status among Palestinian citizens cannot be separated from the issues of nationalism and indigenous minority struggle. This is particularly evident in the emphasis the interviewees for this article placed on the importance of the processes of Palestinization and Arabization next to Islamization. As such, the female Islamist activists interviewed had the same focus as the Islamic Movement generally, which is to teach Palestinians in Israel not only about Islam but also about ancient and modern Palestinian his-

7 Muslim Palestinian women are a very diverse group from different backgrounds across the country, including mixed cities, Palestinian towns and villages, and unrecognized villages largely in the Bedouin dominated Naqab/Negev.

8 Haleh Afshar, Islam and Feminisms: An Iranian Case-study (Basingstoke: Macmillan, 1998), reviewed in Laura Zahra McDonald, "Islamic Feminism", Feminist Theory 9, no.3 (2008), 351, doi:10.1177/1464700108095857. 
tory, including Palestinians' current predicament as indigenous non-Jewish citizens of the Jewish state, as well as to improve their level of Arabic. ${ }^{9}$

\section{The Context: Palestinian Islamist Women in Israel}

As a result of the 1948 war, more than 700,000 Palestinian Arabs, or seveneighths of the inhabitants in the territories that became the state of Israel, were expelled or fled. ${ }^{10}$ Today, approximately 20 per cent of the Israeli population are Arab Palestinian. ${ }^{11}$ According to official data, at present Muslim Palestinians constitute approximately 80 per cent of the 1.5 million Palestinians in Israel (the rest are Christians and Druze, constituting about 10 per cent each). ${ }^{12}$ The overwhelming majority of Muslim Palestinians are Sunni.

While Palestinian citizens of Israel as individuals have civil and political rights, such as the right to vote and to be elected to political representation, they lack a number of collective rights. As a native non-Jewish national minority in the Jewish state, they are discriminated against when it comes to distribution and access to land, economic resources, job opportunities, privileges given to citizens who served in the military, and citizenship rights. ${ }^{13}$ Their predicament is well illustrated by the Law of the Return, which allows all Jews in the world to immigrate but prohibits Palestinian citizens from bringing Palestinian spouses from outside Israel. It is within these boundaries of the opportunities and limitations created by Palestinians' Israeli citizenship and Palestinian national belonging that the Islamic Movement in Israel conducts its activism.

The Islamic Movement in Israel was established in the early 1970s by 'Abdallāh Nimr Darwīsh and others who had been educated in religious institutions in the Israeli-occupied West Bank. It grew from a movement of grassroots activism into a player on the local political field during the mid-1980s. It

9 Tilde Rosmer, “Resisting 'Israelization': The Islamic Movement in Israel and the Realization of Islamization, Palestinization and Arabization", Journal of Islamic Studies 23, no. 3 (2012), 13, doi:10.1093/jis/etso54.

10 Benny Morris, The Birth of the Palestinian Refugee Problem, 1947-1949, reprinted edition (Cambridge: Cambridge University Press, 1989), 1.

11 Central Bureau of Statistics, “66th Independence Day - 8,2 million residents in the State of Israel”, 5 January 2014 <http://www1.cbs.gov.il/reader/newhodaot/hodaa_template. html?hodaa=201411111>.

12 Ibid.

13 Adalah, The Inequality Report: The Palestinian Arab Minority in Israel (Israel, 2011) < https:// www.adalah.org/uploads/oldfiles/upfiles/Christian\%2oAid\%2oReport\%2oDecem ber\%202010\%2oFINAL(1).pdf $>$. 
emulated the Muslim Brotherhood in Egypt in its organization. The movement split into a Northern and a Southern branch in 1996 due to a disagreement over whether to participate in national elections for the Israeli parliament (Knesset). ${ }^{14}$ The Southern branch has since had representatives in the Knesset; the Northern branch, until 2013, governed the city of Umm al-Fahm.

Both branches focus their activism on strengthening Arab, Palestinian, and Muslim culture among Palestinians in Israel on an individual and collective level. Their agendas are direct responses to the de-Islamization/secularization, de-Arabization, and de-Palestinization this community underwent from 1948 until 1967, while it was under military rule and isolated from the surrounding Muslim and Arab countries, as well as from the Palestinian communities in the West Bank and Gaza Strip. From 1966, Palestinians in Israel were exposed to the twin processes of Israelization, which includes both a regime-enforced focus on Israeli history narrative in state education and a natural degree of assimilation to parts of Israeli culture, in particular secularization and de-Arabization. The ideology and activism of the Islamic Movement is disseminated via the branches' state-wide network of mosques and educational and social organizations, which cater for the needs of their constituencies "from the cradle to the grave", including providing social and educational support that these citizens are not receiving adequately from the state. Most of the movement's organizations and activities are gender segregated..$^{15}$

In addition to being marginalized by the Israeli state and society as nonJews, and as a potential enemy, Palestinian citizens of Israel are also marginalized within their Palestinian nation, where they have little influence and have rarely been designated a role or position. Palestinian citizens of Israel have accordingly been described as a "trapped minority":

A trapped minority is a segment of a larger group spread across at least two states. Citizens of a state hegemonized by others, its members are alienated from political power. Unable to influence the definition of public goods or enjoy them, its members are at the same time marginal within their mother nation abroad. ${ }^{16}$

14 The Northern and Southern terminology refers to the locations of the towns in which the first leaders of the two branches (Rā’id Șalāḥ and Darwīsh) lived in the so-called Triangle, an area of central Israel primarily inhabited by Palestinian citizens of Israel. It does not represent a real geographical division of the branches.

15 Kāmil Rayān, interview by author, July 2008; Najāh Saṭl, interview by author, July 2008; observations during fieldwork.

16 Dan Rabinowitz, "The Palestinian Citizens of Israel, the Concept of Trapped Minority and the Discourse of Transnationalism in Anthropology", Ethnic and Racial Studies 24, no.1 (2001), 1, doi:10.1080 / 014198700200065552. 
Adding to this is the patriarchal dimension of male power over women. Hence, Palestinian women in Israel can be described as being trapped within a trapped minority, as state policies, together with practices of patriarchal subordination of women, "support each other at the expense of women's political development and empowerment."17 This is a consequence of the combination of colonial attitude towards Palestinians in Israel and of Palestinian reactions to their marginalization. The patriarchal patterns marginalizing Palestinian women in Israel are:

the fruits of state policies of pseudo-cultural sensitivity towards the Palestinian population that reproduces an image of the Palestinian community as traditional and religious, and on the other hand, the fruit of the desire of Palestinian men to preserve an image of authenticity and autonomy from Jews. It preserves the power of the patriarchal assumptions inherent to both liberal democracy and traditionalist Arab culture often associated with Islam. ${ }^{18}$

Similar to the Egyptian Islamists studied by Ahmed, the woman becomes the carrier of cultural and political competing discourses. Ahmed describes how in Egypt "the debate over women became a dominant mode through which these other profoundly diverse matters were contested." ${ }^{19}$ Veiling and gender segregation became a tool to practise and show resistance to Israeli political and cultural domination, and since these practices first of all affect the (Islamist) Muslim community itself, it was a trouble-free resistance that the Israeli authorities did not resist. However, in most research and media reporting, the reality of multiple challenges that face Palestinian women in Israel is reduced to one issue, while their struggles against patriarchy, and indeed their successes, are ignored altogether: "Research on Palestinian women in particular has been distorted and one-sided. It has aimed to show Palestinian women as powerless, dependent and victims of patriarchy and Arab male oppression."20

In Marion Boulby's study of women's role in the Islamic Movement in Israel - the first specialized study of this topic - it was argued that the movement has contributed to the emancipation of Muslim Palestinian women, but only within the limitations of patriarchy. ${ }^{21}$ The emancipatory contributions are an

17 Suheir Abu Oksa Daoud, Palestinian Women and Politics in Israel (Gainesville: University Press of Florida, 2009), 4.

18 Lauren Erdreich, "Strategies against Patriarchy: Sexualized Political Activism of Palestinian Israeli Women on Campus", Israel Studies 11, no.1 (2006), 39 <https://muse.jhu.edu/ article/194546>.

19 Ahmed, A Quiet Revolution, 129.

20 Daoud, Palestinian Women, 2.

$21 \quad$ Boulby, "Women and the 'Islamic Movement". 
increased opportunity and encouragement to pursue higher education and to work outside the home (and also outside traditional workplaces). Yet the Movement upholds the main role of a woman as a mother and to bring up the new generation, and thereby the guardian of the Islamic heritage. Thus the Islamic Movement simultaneously instigates the seemingly contradictory process of challenging certain patriarchal patterns while it reasserts others.

The present article finds that the female student Islamist activists interviewed for this research are products of this dynamic and can be described as agents of change who challenge and transform their traditionally given roles through their act of studying and choosing to be Islamist activists at Israeli university campuses, while simultaneously continuing patterns of gender segregation. The following analysis will first focus on the reasoning behind these activists' efforts to empower women by educating them about what they consider to be prevalent wrong interpretations of the role and position of women in Islam. It will also focus on their choice to wear the hijäb and be Islamist activists. This will be followed by an examination of their views on education, marriage and work, and their roles as wives and mothers. Lastly, the article will explore their views on gender segregation and public roles for women.

\section{Critiquing Misunderstood Practices}

Over the years of researching the Islamic Movement in Israel, I have been told by several interviewees that women, rather than men, often made the first steps towards an Islamic lifestyle and activism. ${ }^{22}$ Far from being coerced, they were interested in and often introduced their husbands and/or families to revivalist Islam. Najāt Sațl (Najah Satel) is a pioneer among the women in the Islamic Movement. She was in her forties when interviewed and belongs to the first generation of female Islamist activists in Israel. As such, she represents one of those who paved the way for the young student activists interviewed for this research, and from her story and views on activism the boundaries and context of the next generation activists are presented.

Sațl is from the mixed city of Jaffa, where she works for the local shari'a court as an arbitrator and is considered to be one of the informal female leaders of the Southern branch. She is married to the local imam, who also is the local representative of the Southern branch of the movement, and she has four children and grandchildren.

As a child, Sațl attended a Christian school in a predominantly Jewish neighbourhood. She described her parents as traditional Muslims who were 22 Rosmer, “The Islamic Movement”; Rosmer, "Resisting 'Israelization"; Rosmer, "Raising the
Green Banner". 
not religious and were "good simple people, who taught me to adapt to the situation and be a good citizen". ${ }^{23}$ She described herself as not knowing much about either Islam or about Palestinian history as she grew up. As a young teenager she began asking questions about who she was and about the history of her country and people. Growing up in the 1980s, her ignorance was the result of a process of Israelization, which can be viewed from two perspectives. One perspective holds that her ignorance was the result of state-led measures towards its Palestinian citizens intended to subdue their Arab Palestinian sense of belonging and related political alliance, and strengthen their position as acquiescent "Israeli Arabs", enforced through controlling their education, as well as their economic and political opportunities. ${ }^{24}$ Another perspective presents Israelization as the expected influences on the sense of belonging among Palestinian citizens, their culture and lifestyle, by living and working in Israel and through the resulting exposure to, and to a degree participation in, Hebrew and Israeli media and mainstream culture. ${ }^{25}$

Despite, or possibly because of, both these sides of the process of Israelization, a process of re-Palestinization emerged, beginning in the mid-196os, according to Rouhana. In the 199os he found that (1) few Palestinian citizens would describe themselves solely as 'Israeli'; (2) there had been a steady increase in the tendency to describe the collective identity of the Arab population as 'Palestinian'; (3) national identity remained consistently central; and (4) there was a negative correlation between the suitability of the terms 'Palestinian' and 'Israeli.'26 The Islamic Movement in Israel is one of the organizations that, through its dual focus on the Palestinian context and predicament, combined with its Islamist outlook, works to empower Palestinian history and a national sense of belonging among Palestinian citizens in Israel.

Saț's engagement with both the Arab Palestinian and Muslim sides of her self-identification was enhanced when she transferred to a Muslim high school in the 1990s, where she was taught about Islam, and this increased her appetite to learn more about her religion and also about her national Palestinian belonging:

\footnotetext{
23 Sațl, interview by author.

24 Nadim N. Rouhana, Palestinian Citizens in an Ethnic Jewish State: Identities in Conflict (New Haven: Yale University Press, 1997), chapter 2.

25 Sammy Smooha, "The Advances and Limits of the Israelization of Israel's Palestinian Citizens", in Israeli and Palestinian Identities in History and Literature, eds. Kamal AbdelMalek and David C. Jacobson (New York: St Martin's Press, 1999), 13-14.

26 Rouhana, Palestinian Citizens, 113.
} 
I found myself in this situation, knowing that we live in such a diverse society, with people of many different roots; therefore you need something to identify yourself, to be a part of the group. You have your identity; you have your classification. At that time, thank God, I succeeded, and religion really helped me see the other [the Jewish-Israeli] as the other and not to assimilate myself in the other and be part of the other, which, substantially is not me.

Sațl told me that she read books and asked questions to satisfy her need for knowledge about the development and traditions of Islam. She went on to be one of the initiators of one of the first Islamist groups for women in Israel in the 1990s. The group was established to assist Muslim women in "forming their identity and returning to the roots and begin[ning] to live, in my view, with the new true identity". The focus was on strengthening women in their personal lives and increasing their knowledge about their status and rights according to Islam. Sațl emphasized that they work within the framework of Israeli law and that their activism is "non-threatening" (for the state and Jewish Israeli citizens). Her organization was part of the many new women's organizations connected to the Islamic Movement that appeared in the 1990s in Palestinian cities, towns, and villages and that focus on charitable, educational, and social programmes for women and children. ${ }^{27}$

Today their organization is part of the larger (Southern) Islamic Movement, or, in Sațl's words, "we are like a movement in the [Islamic] movement". This is significant, because, similar to the student organizations discussed below, this indicates that the establishment and activities of the Islamist groups for women are recognized as part of the male-run mother movement. As such, first of all, they influence the larger movement from within, not as a pressure group from the outside; however, second, being part of the movement also means that these women have to fit their challenges to what is considered permissible by the movement's male leaders. In other words, being a part of the Islamic Movement concomitantly provides female activists the opportunity to influence the movement while limiting the degree to which these women can act independently and thus how far their criticism can go. However, it is difficult to assess when they are self-censoring and when they are being indirectly or directly told where the red lines are.

Sațl argues that women's rights, gender equality, and social justice are Islamic values, and she advocates conducting rereadings of the Qur'an and other religious texts to support these claims: 
In the last century, women have been deprived by the way Islam has deviated from, and all the ideas of Islam were really distorted and parts of Islam were taken out and applied to women. Women were not allowed to go out, not allowed to lead a private life, even an independent economic life has been forbidden as if she is owned by or under domination and not a partner to a husband or to a man in society - she was really under domination. Today, we are more exposed to religion, to all these issues that were not true, but only convenient to the "male" society to subjugate women [so they would] be just women who remain at home, housewives, not individuals with independent lives who make decisions and express their opinions and have a status. ${ }^{28}$

Women studying and preaching Islam is not new among Palestinian citizens of Israel. From the early days of the Islamic Movement's development, in the 1970 s and 1980s, both men and women went to West Bank cities, in particular to Nablus and Hebron, to study Islam at the seminaries there. ${ }^{29}$ It was these students who established the Islamic Movement in Israel when they returned home. This flow of religious learning has since stopped, after the government decided not to allow Palestinian citizens to be educated in the occupied Palestinian territories.

Sațl describes her inspiration for activism as being her desire to improve the marginalized status and position of (Muslim) women. The method is to teach women about rereadings of the Qur'an and other religious texts to support them so that they can demand their rights by relying on Islamic sources. In our interview she did not specify which text and interpretative methods they use; instead, she focused on the importance of spreading knowledge about opportunities for women in accordance with Islam among Muslims in Israel, thus countering what they consider to be misinterpretations of the female role that hinder women in their educational and personal development vis-à-vis men. By arguing that women's rights, gender equality, and social justice are Islamic values, Saț and her contemporaries were arguably acting as Islamic feminists. ${ }^{30}$ "Islamic feminism" is a controversial category due to the history of Western feminism and its Orientalizing, and at times racist, expressions and (mis)use in

\footnotetext{
28 Sațl, interview by author.

29 Ibid.

$30 \quad$ Marianne Bøe and Liv Tønnesen, "Nye utfordringer til islamsk feminisme: Kvinneaktivismens mange ansikter i Sudan og Iran ["New Challenges to Islamic Feminism: The Many Faces of Women's Activism in Sudan and Iran"], Tidsskrift for Kjønnsforskning 35, no.4 (2011), 327-42 <https://www.idunn.no/tfk/2011/04/arto5>.
} 
imperial interventions in the region. ${ }^{31}$ However, when used in the manner that Ashfar and others have done, it means the struggle "to change the position of women in society, but not the frame of Islam itself". ${ }^{32}$ This style of rereading religious texts neatly fits Sațl's description of what they were doing. The establishment of organizations working to improve Palestinian women's rights within the framework of Islam in Israel in the 1980s and 1990s was part of the general development of Palestinian civil society in Israel, which in turn was part of the development in Israeli civil society, together best illustrated by the fact that more than a thousand Palestinian NGOs were formed in Israel between 1980 and $2003 .{ }^{33}$

In addition to her commitment to proselytize about women's role and position in Islam, Sațl called attention to the need among Palestinian citizens for knowledge about Palestinian history - Arabic and Islam generally - which had been suppressed by state policies, first under military rule, and then as part of the twofold process of Israelization. In order to follow her conviction, Saṭ chose to pursue higher education and become an Islamist activist, a choice also made by the student interviewees discussed below.

\section{The Element of Choice: hịjāb and Islamism}

Ghāda is a young law student at the Hebrew University in Jerusalem. She was active in the administration of the Islamic Movement's student association for women. Ghāda comes from a secular family and village, where people predominantly adhere to the socialist coalition party, the Democratic Front for Peace and Equality (al-Jabha al-dīmūqrātiyya li-l-salām wa-l-musawāh). She told me about her gradual personal transformation from being secular to becoming religious:

I found that the Islamic thing is broader, and as a Communist, I had a lot of ideas about Islam that were actually anti-Islam. I started to read and interact with people. I understood that my thoughts were prejudiced and not based on sound ideas.

\footnotetext{
$31 \quad$ McDonald, "Islamic Feminism".

32 Ibid, 351.

33 Shany Payes, Palestinian NGos in Israel: The Politics of Civil Society (New York: Taurus Academic Studies, 2005), 1.
} 
When she started university, Ghāda considered it natural to become active in the student association belonging to the Islamic Movement. In general, all student activists interviewed, male and female, described how they had become Islamist activists because of their previous relations with the movement's organizations in their home town or village, because of their religious upbringing, or because of their political frustration as Palestinian citizens of Israel, or because of a combination of these reasons. ${ }^{34}$ As such, the motivation of the female students interviewed for this research has not been markedly different from their male peers.

The element of choice is also evident when my interviewees talked about their decision to cover their hair. For Ghāda, starting to wear the hijā b was a big step, since most of her town, including all her friends and her extended family, are secular. She said that the reactions in her town were negative. However, at university she has experienced non-religious and religious students socialized without any problems and agreeing on many issues when getting to know each other.

Sațl, who began wearing the hijäb in the late 1980 s, when few young Palestinian women in Israel did so, spoke about negative reactions from both Palestinian and Jewish Israelis. She recalled episodes of verbal attacks and remembered how other covered women also talked about such public experiences. There are also stories about covered women who were suspected by Jewish Israelis of being terrorists and who were asked to show identification and in some cases were told to leave the premises or come to the police station to make a statement. Sațl spoke about reactions she faced from her Jewish fellow students, whose perception of an Arab Muslim woman, and in particular a covered one, was that of a powerless woman whose place was in the kitchen and not at an evening course at the university.

The wearing of the hija $b$ increased among Palestinians in Israel from the late 1970s, after the authorities ended military rule, which enabled Palestinians to connect with the development in the surrounding Arab Muslim world physically - by going to the occupied West Bank and Gaza Strip (where the firstgeneration Islamists in Israel were educated) - and religiously - by taking up new ideas thanks to the increased availability of books and media. The trend among women across the region in the 1970 s was to begin wearing the veil, reasons being found in the combination of the Arab states' defeat in the 1967 war with Israel, Islamist groups' strengthened position in society, Saudi Arabia's increasing economic and religious-cultural position and influence, and 
the empowerment felt by women when wearing the headscarf. ${ }^{35}$ In 1978 the Israeli state allowed Palestinian citizens to travel to Mecca for the hajj for the first time. Based on the idea that Muslim women are supposed to wear the hijāb after completing the hajj, those who returned became symbols of the custom. ${ }^{36}$ This year thus became a visible turning point in terms of women choosing to wear the hijāb. In addition, increasing numbers of religious schools and institutions also encouraged young women to cover their hair.

Not that covering hair was an entirely new idea. The Palestinian hijāb is in many cases more of a headscarf - Christian women, especially nuns, also wear such scarfs. ${ }^{37}$ As such, the young generation Palestinian women in Israel were continuing the traditional practices of their mothers and grandmothers. While these women made their choice based on new thinking inspired by Islamic perceptions of modesty, they were also protesting Israeli political subjugation and cultural domination, similar to the way in which, in the Egyptian case studied by Ahmed, it was a protest against Westernized colonial domination using authentic local traditions, as discussed above. ${ }^{38}$ Furthermore, since donning the veil was a deliberate choice made by young women, the act could also be understood as an implicit challenge of patriarchal social patterns. As Erdreich writes:

while these women ostensibly preserve the social order by wearing the hijab, their choice to do so integrates a rational individual element that empowers them, not only in their connection with God, but also in terms of the gender-blind western discourse of individualism. ${ }^{39}$

Based on the stories from the interviewees about their desired turn (or return) to Islam and Islamic activism, including their preference to wear the hijāb, these women clearly have agency, as well as knowledge and freedom, to make up their own minds and act on their own decisions. By making their own choices, some had to face familial and social opposition. In addition, they encountered reactions from the majority Jewish-Israeli society. The next section discusses the student interviewees' choices in education and their related aspirations for their future professional and family lives.

\footnotetext{
35 Ahmed, A Quiet Revolution, 208-34.

36 Daoud, Palestinian Women, 103.

37 Ibid.

38 Ahmed, A Quiet Revolution.

39 Erdreich, "Strategies Against Patriarchy", 47.
} 


\section{The Educated Mother}

For Palestinian citizens of Israel, reproduction and the role of women are associated with nationalism. ${ }^{40}$ However, there are changes happening. Previously, Palestinian pronatalism was an expression of nationalism and opposition to Israeli state policy, which was designed to lower the birth rate among its Arab citizens in order to win the assumed "demographic war". ${ }^{41}$ Today the new discourse among Palestinians in Israel centres on limiting the Palestinian birth rate among the educated professional middle class as a new method in the same national struggle. Instead of using numbers to resist Israeli domination, Palestinians in Israel today use education to partake socially and politically in order to fight for their rights and against their discrimination. The students interviewed for this research are part of the latter discourse. They said that they wanted to continue their studies or work after becoming married and, if possible, also after becoming mothers.

As such, these students challenge the traditional model of the stay-at-home mother and also of the mother who works in a job near her home that is convenient but not necessarily relevant to her education. In the 1950s there were only a handful of female Palestinian students at Israeli universities, but since the mid-1980s their percentage has increased from around 30 per cent to over 50 per cent in the 1990s. ${ }^{42}$ In 2015, 14.4 per cent of bachelor students and 10.5 per cent of master's degree candidates were Palestinians, of which 67.2 per cent were women. ${ }^{43}$ Among Palestinian PhD candidates (all together, 5.9 per cent), women make up 71 per cent. ${ }^{44}$

The high number of Palestinian women in higher educational institutions in Israel is due to the fact that "all segments of Palestinians in Israel, regardless of their gender, strongly support higher education among women." ${ }^{45}$ Being part of this trend, the Islamist student activists interviewed did not choose to become teachers or nurses, jobs typical for a practical combination with the

40 Rhoda Kanaaneh, Birthing the Nation: Strategies of Palestinian Women in Israel (University of California Press, 2002), 62-65.

41 Ibid, 50-56.

42 Representation of Arab Citizens in the Institutions of Higher Education in Israel, ed. Nohad Ali (Haifa-Jerusalem: The Association for the Advancement of Civic Equality [Sikkuy] November 2013) <http://www.sikkuy.org.il/wp-content/uploads/2013/11/English_final2014_representation_higher_educationı.pdf>.

43 Yarden Skop, "More Arab Students in Israel Attending University in New Academic Year", Ha'aretz, 15 October 2015 <http://www.haaretz.com/israel-news/.premium-1.680454>.

44 Ibid.

45 Daoud, Palestinian Women, 66. 
role as wife and mother. Rather, they studied law, IT, Middle Eastern studies, psychology, and sociology, and all described having made their choices of study on their own. What is more, they lived in campus dormitories far from their families and communities. This indicates independence and freedom of choice provided by their parents. As described in another article by this author, which focused on Islamist student politics in Israel, living far from home, surrounded by Jewish Israeli culture and people, can be difficult for Palestinian students. ${ }^{46}$ They have to share dormitories with mostly secular Jewish students, who often have a different view and practice of gender and sexual relations. Many interviewees described discomfort knowing that their Jewish peers had male visitors and that they might meet these male visitors in the shower rooms or in the kitchen late at night.

Yet the dormitories and life away from home also provide opportunities for self-development as Muslim activists and as young independent women. The dormitories and campus are the spaces where they conduct their outreach and proselytization activities $\left(d a^{\prime} w a\right)$. They invite other Muslim girls to join in a meal and a chat or an informal group session covering various aspects of Islam. They read the Qur'an and other sources, discuss aspects of the texts and of practising Islam, and share their experiences.

As for most students everywhere, this is the time and space where they have the chance to live without their parents or community observing and assessing them. The young female Palestinian students' time at university has been described as a "liminal phase" during which these young students live away from home and the control and support of the family, and have room to develop new ideas and challenge accepted norms. ${ }^{47}$ It can also be described as liminal in a gendered status manner - as students, they are between being girls, defined as "not married", and women, defined as "married". Thus university studies offer these young students the opportunity to live outside of their community's patriarchal organization.

However, this does not mean that the topic of marriage does not preoccupy them. All the female (as well as male) students interviewed for this research expected to be married. Becoming a wife and a mother is important to these young women. The centrality of marriage for Palestinian women students at Israeli universities is illustrated by the title of Erdreich's article "Marriage Talk". Young students talk about the constant pressure from their family to get married, while simultaneously enjoying gossiping about friends and family

\footnotetext{
46 Rosmer, "Raising the Green Banner", 35.

47 Lauren Erdreich, "Marriage Talk: Palestinian Women, Intimacy, and the Liberal NationState", Ethnography 7, no.4 (2006), 495 <http://www.jstor.org/stable/24047927>.
} 
members' weddings and marriages. ${ }^{48}$ They are also aware of the view of the older generation, and their (male and many female) Islamist leaders, that a woman's main role is to be a mother and to bring up the new generation. ${ }^{49}$

Thus the young interviewees are dealing with their desire, on the one hand, to get married and become mothers and, on the other hand, to be professional, independent women, a dilemma shared with the majority of educated women in the world today. However, whereas how to practically address this predicament is discussed generally and by feminists specifically in Europe and other places, these students did not display any concerns about this highly potential dilemma. One explanation as to why they did not voice any concern that they might not be able to utilize their education after getting married, or becoming mothers, might be because they all expected to marry equally educated men from their own generation. In other words, they seem to trust that their (to my knowledge, unknown) future husbands will agree that they can and should work in a relevant job in addition to being a wife and a mother. This indicates that they don't expect patriarchal limitations within their marriage to their opportunity to have a professional life.

In terms of employment possibilities, however, it should be added that Palestinian professional women face challenges on several levels. First, as Palestinian women they will have difficulties finding a job due to their double predicament as Arab women in Israel, and this is made even harder because they are likely to move to their or their husband's village or town, where the employment market is small. Their opportunities are restricted by being trapped inside this trapped minority - Palestinian women in Israel have one of the lowest rates of employment in the world. ${ }^{50}$ Further adding to their predicament is the fact that childcare is expensive, if available at all, in Palestinian communities. The Islamic Movement has sought to address this shortage by providing nurseries at subsidized costs across the country. Satl was the only interviewee in this article who had a family. She described her choice to be a working mother as "a positive burden" and said that she had withdrawn from her master's degree studies in order to be a hands-on mother. Similar to working mothers worldwide, she expressed feeling constantly guilty for not always being available to her children because of work. Nevertheless, she likes her job, is passionate about it, and refuses to give it up.

Whereas the student interviewees have yet to experience these challenges, many other interviewees who are married have either paid work or are

\footnotetext{
48 Erdreich, "Marriage Talk".

49 Boulby, "Women and the 'Islamic Movement”, 492.

5o Adalah, The Inequality Report, 9.
} 
volunteers in one of the Islamic Movement's organizations. ${ }^{51}$ Some said Islamic activism was easier to combine with raising small children and therefore the best solution at that time, and that they can progress their own career later when family life is less demanding. From the survey conducted for this article (with 53 students, 32 of whom were female), 65 per cent confirmed that they intended to be active in the movement after their studies. However, only 41 per cent said they would be active in politics after they graduate from university, and 39 per cent said they "don't know". We might infer from this that if these women are not able to find employment or cannot take on employment due to duties at home, they will probably be active in the local Islamic Movement's associations.

Since the interviews with the female students were conducted, the Northern branch of the Islamic Movement has been outlawed (in November 2015), as have all of its organizations. As a result, women in paid and volunteer positions in these organizations have lost their employment or engagement. In addition, women (and the entire constituency) relying on the organizations of this branch have lost the social, religious, educational, and financial support provided by it. ${ }^{2}$

In sum, the picture emerging of these young women and their roles and possibilities within the framework and mindset of the Islamic Movement in Israel is not limited to the traditional roles of being a mother and wife. The fact that so many young women from and associated with the movement are at Israeli universities studying with the intent and hope of future employment, indicates that they are taken - and take themselves, their desires, and abilities seriously. However, their roles have not yet reached the movement's upper echelons, and they are part of upholding the pattern of gender segregation that enables this limitation, as will be discussed below.

\section{Self-Imposed Segregation: Limitation or Instrumental?}

Even though the women's organizations of the Islamic Movement played an important role in encouraging women to take local and sometimes countrywide public roles, the Southern branch of the Islamic Movement has not promoted women to the Knesset since it first participated in national elections in

\footnotetext{
51 Female activists in the Islamic Movement, interview by author, November 2013.

$5^{2}$ Samah Salaime, "Meet the Outlawed Women of Israel's Islamic Movement", 972mag, 16 January $2016<$ https://972mag.com/meet-the-outlawed-women-of-israels-islamicmovement $/ 116001 />$.
} 
1996. When explaining this position, former Member of Knesset for the Southern branch 'Abd al-Mālik al-Dahāmshah (Abdel-Malek Dahamsheh) struggled to reconcile the contradictions. On the one hand, he tried to show openness towards women's political participation. Most spokespersons of the movement want to demonstrate that it embraces women, in order to fight back against stereotypes of being "extreme" and "backward", as it is often described in the Israeli Hebrew media and by the current Netanyahu government. ${ }^{53}$ On the other hand, al-Dahāmshah adhered to the traditional patriarchal view: "I do not object to women's participation and representation in politics, but we have to protect women's honor. The main role for women is in the home - raising children and managing the household". 54

The promotion (or not) of women to prominent political positions has to be viewed in the context of the Palestinian community at large. Hanin Zu'bì (Hanin Zoabi) was the first female representative of a Palestinian political party to be elected to the Knesset, in 2009, for the secular party, the National Democratic Alliance. Thus the Islamic Movement cannot be said to be far behind its secular counterparts when it comes to promoting women to this level. In fact, the Southern branch has repeatedly nominated women candidates for local and municipal councils. As such, the movement "is making efforts and significant progress in promoting women, not through elections, but through appointments", compared with the two main secular political parties, who "have failed to meet women's demands for positions of power and to meet the parties' own agendas for women's representation". ${ }^{55}$ One example is a female Islamic politician who was elected local council member and who stated that she would be willing to continue her political career only if encouraged to do so by the movement. ${ }^{56}$ There were talks about her running for the Knesset, but this never materialized.

The Islamic Movement also mobilizes women in elections and vote competition, and places significant importance on their role in these. It does so for

To illustrate: Brenda Gazzar, "Israel's Islamic Movement: Filling the Vacuum, Aiming for a Caliphate", Jerusalem Post, 3 August 2008 <http://www.jpost.com/Israel/Israels-Islam ic-Movement-Filling-the-vacuum-aiming-for-a-caliphate>; Ariel Ben Solomon, "Israeli Arabs Protest Ban on Islamic Movement", Jerusalem Post 21 November $2015<$ http://www. jpost.com/Arab-Israeli-Conflict/Israeli-Arabs-protest-ban-on-Islamic-Movement -434875>; Uzi Baruch and Dvorin, "Islamist Sheikh Raed Salah's Travel Ban Extended to December", Arutz Sheva Israel National News, 2 July $2014<$ http://www.israelnational news.com/News/News.aspx/182444\#.U98vyVcfN3s>.

54 Daoud, Palestinian Women, 200-01.

55 Ibid., 203.

56 Ibid., 131-32. 
three reasons. First, it wants these women's votes. Second, it wants them to, and believes they can, influence the vote of their husbands. And third, it wants to encourage other women to vote for it, doing so by sending women door to door during political campaigns. ${ }^{57}$ Certainly this can be described as exploiting women, but it may also indicate an appreciation of their role and position in the home and in society at large.

From the female activist interviewees' perspective, it seems of greater importance to assist women in achieving progress in their everyday lives than to have women in high political positions, such as in the Knesset. Their focus is on (female) solidarity and empowerment, as well as on the need to correct what they claim to be misunderstood ideas about the role and status of women in Islam, as discussed above. As for political aspirations, when asked how far a Muslim woman in Israel can reach today, Sațl replied:

I still have not seen myself at a level where I aspire, not just personally, but also our female movement, to arrive at the position to represent ourselves politically in the Knesset. We still have not reached this level in our organization. We are more into the self-empowerment of women with regard to their status and forming their identity that was distorted for many years.

This reluctance to put a woman in the front at a mixed-gender meeting, and to focus on the content rather than on the presentation or positioning of the Islamist message, is also visible in the organization of Islamist student activities. The aims of the student associations of both branches of the movement are to increase awareness and knowledge about both Islam and their Palestinian Arab history, and to help the students practically in their studies and lives on campus. ${ }^{58}$

To this end, events and information organized by the student associations include lectures by academics and politicians, information on the associations' websites, and demonstrations and protests in response to political events, such as during the wars in the Gaza Strip in 2009, 2012, and 2014. As for increased knowledge of the Arabic language, since these students study in Hebrew, the associations carry out a variety of events, including reading groups, poetry, and stand-up evenings. Finally, in order to increase the awareness of Palestinian

57 'Ādil Badīr, interview by author, May 2010.

$5^{8}$ Rosmer, "Raising the Green Banner", $3^{2}$. 
history and current predicament, the associations provide literature and schedule lectures and trips to Palestinian communities in Israel. ${ }^{59}$

The students' religious awareness is increased through activities such as lectures by religious leaders, smaller gatherings with preachers, and regular small reading groups on campus led by student activists. In addition, the students go to pray at the Al-Aqșā mosque in East Jerusalem on a weekly basis, though this activity depends on the Israeli authority's daily decision to grant access to the holy site and the Old City. It is easier for Palestinian citizens of Israel to access Al-Aqșā than for Palestinians from occupied East Jerusalem, and especially from the West Bank, since the latter are prevented from entering the city by a strict system of permits, by the separation wall, and by military checkpoints. The decreasing ability of Palestinians under occupation to access the city and the holy sites is precisely one of the reasons why the Islamic Movement makes the effort to assist Palestinian citizens to get to the city and the mosque. ${ }^{60}$ The dual reasoning is to assist the increasingly impoverished and isolated community in East Jerusalem and to make sure that the holy site is in use and looked after. $^{61}$

In addition to activities focused on increasing awareness about Islam, the Arabic language, and the history and current predicament of Palestinians, the student associations of both branches of the movement offer practical assistance to all Palestinian students, including financial assistance, such as selling meal tickets and copy cards to students at reduced prices, and granting scholarships to students for teaching in villages and for tutoring new students. ${ }^{62}$ Assistance with the Hebrew language, especially in the first year of study, is another important activity, in addition to general tutoring for new students.

The student associations also provide social support for new Palestinian students. As discussed above, this is the first time these students have lived on their own, away from their families and communities. In addition, they stay in dormitories with Israeli students who have a different lifestyle. Apart from issues related to Israeli students having girlfriends or boyfriends visiting, another concern mentioned by several students was that they disturb their Israeli roommates when they get up to pray at dawn. ${ }^{63}$ The students also complained that there are insufficient prayer rooms, if any, available for them.

\footnotetext{
59 Ibid.

$60 \quad$ Rosmer, "Resisting 'Israelization”, 19.

$61 \quad$ Ibid

62 Rosmer, "Raising the Green Banner", 35.

63 Ibid.
} 
Female student activists are described as being more involved and committed than their male counterparts. ${ }^{64}$ Scholarship programmes, run by both branches of the movement and which involve students going back to their home village or town to teach pupils, were initiated by female students. In addition to providing the students with a source of income and experience in teaching, and offering needed assistance for the pupils, this activity is considered as outreach and thus is also a form of Islamic da'wa activism, incorporating elements of Arabization and Palestinization. According to one of the women student activist leaders interviewed, even after male students became active in this activity, she still estimated that 70 per cent of the students who participate in this scholarship programme are women. ${ }^{65}$

In general, all student activities described above under the auspices of the Islamic Movement's student associations are for male and female students. They are gender segregated when the events or gatherings are small, and mixed when the events are large, such as during film screenings, lectures, and trips outside campus. This was presented by the interviewees as a fact and how it ought to be. It is important to emphasize that the identical parallel activities for and by male and female students are not differentiated by content or quality, but purely divided by gender, and they therefore challenge the basic idea behind the traditional segregation into male-rational space and female-biological/sexual space. ${ }^{66}$

It can be argued that student activists follow the traditional gendered organization of Islamist movements, thereby reproducing the ideal of the patriarchal society by separating men and women. However, as discussed above, there is more to this practice than meets the eye. Islamic Movement activists use segregration to preserve sexual morals by controlling the mingling of men and women, but they also use it to express their national belonging and resistance to Israelization. Similar to how the veil in Egypt became a symbol of national identity and authenticity vis-à-vis the West in the $1970 \mathrm{~s},{ }^{67}$ the self-imposed (or at least unchallenged) segregation of these students can be understood as a way to both show and foster their Palestinian Arab Muslim belonging vis-à-vis the largely secular Israeli state and society. In other words, by upholding the old tradition of segregation, albeit in a new form outside of Palestinian-dominated areas and largely controlled by the students themselves, they are partak-

\footnotetext{
64 Ibrāhīm Hijāzī, interview by author, January 2012.

65 Female student, interview by author, February 2012.

66 Erdreich, "Strategies Against Patriarchy", 48.

67 Leila Ahmed, Women and Gender in Islam (New Haven, London: Yale University Press, 1992), 130.
} 
ing in keeping their traditions and reclaiming their authenticity threatened by the processes of both forced and assimilative Israelization. In this context, the threat of Israelization is twofold: it is the subjugation of the Palestinian minority in Israel and also the influences of secular Israeli society.

On an internal level, by upholding segregation these students display to the movement's leaders that they can be trusted while living away from their families and communities. Retaining this trust is probably important for the female Islamist activists. As discussed above, the student associations and their activities, including those of the female sections, are coordinated and supported financially by the Islamic Movement's national manager, who is employed by the respective branch of the movement, a fact which inevitably affects their degree of independence. True, such interaction may provide an opportunity to exert influence from within, and both the national leadership and student activists described the student associations as being run independently by the student activists at the different universities, and all interviewed students emphasized that they are free to do what they want and that not all activities are coordinated with the national manager. However, since the national managers are older, employed by the movement, and provide financial support to the association, we can assume that their guidance has a large degree of influence.

Lastly, segregation is also considered to provide a safe and comfortable space for women students, especially as they generally come from villages with more traditional mothers, similar to the experience of young Egyptian women in the 1980 s and $1990{ }^{6},{ }^{68}$ and now have to navigate living in an urbane Israeli space and in dormitories where they are faced with different gender relations and sexual morals, as discussed above.

A challenge to the gender segregation among the Islamist students occurs when the Islamic Movement's students' associations hold large events together with the other associations representing Palestinian students. The other main student associations are related to political parties representing Palestinian citizens of Israel, including the nationalist National Democratic Alliance and the socialist-communist National Front for Peace. These two secular parties want to have female speakers at public events. However, this is not acceptable to the Islamist students, who believe that men and women can be at the same events but that women should not address a mixed crowd. This reasoning is presented by the activists, male and female, without question or room for discussion. Sometimes the disagreement over female speakers at joint events has led to events being cancelled or being uncoordinated. As explained by one female Islamist student: 
For example, in terms of association, we believe in the separation between male and female. It is a small issue, but they focus on it [they say]: 'When we want to have an activity for the Arab Students Committee, we want to have association between the sexes, we want to have a female facilitator'. Having a girl [speak in public] is not very acceptable to us, and we have some reservations. They focus on the things we differ on and forget that there are many issues in common between us. ${ }^{69}$

This student claimed that the reason for the secular associations to demand female speakers at their joint events was not feminism, but politics, meaning that the other associations are using this difference strategically in their competition for student votes. In theory, this claim can of course be made also of the Islamist students' insistence on not having female speakers. However, in terms of numbers so far, this only benefits the secular organizations. In 2008 one of the Islamic Movement's student associations won elections to the Arab student councils at the three largest universities in Israel. This landslide victory was a shock to many, including the secular Palestinian student groups, which until 2008 had dominated Palestinian student politics in Israel. It is in this context that Islamist student activists interviewed secular student activists accused of using gender politics to sabotage the Islamists' success. They explained that since failing to organize joint events would reflect badly on the leading association, the secular student activists were causing problems by insisting on female speakers. As the argument went, when the disagreement over this resulted in cancellation of events, it gave the association of the Islamic Movement "a bad reputation". ${ }^{70}$ Whether or not these accusations are valid, it is interesting how the Islamist student activists perceive gender issues as being part of their inter-Palestinian political differences and strategies.

Insisting on not having female speakers can also be understood as yet another way to resist Israelization, in this context in the shape of assimilated secularization, implicitly critiquing the secular nationalist student associations for being too Israelized by copying Israeli gendered social behavior.

In sum, it might seem curious that at university, where, as described above, the students are in a "liminal phase" that provides freedom from familial and social constraints and thus offers opportunities to challenge societal norms, these Islamist students choose to uphold gender segregation to the point where it jeopardizes their joint protests with the secular students' associations

69 Female student, interview by author.

70 Ibid. 
against state policies. However, this can be understood by the multilayered explanations of using gender politics to reassert their identity vis-à-vis the state and Israeli secular society, as well as vis-à-vis the non-religious and non-Muslim student associations; and using it to indicate to themselves and their mother movements and parties that they are serious and able to uphold traditions and do not give in to pressures to change beyond certain limits. Therefore, segregation is a way to display sincerity and authenticity for the young Islamist activists.

\section{Concluding Remarks: Islamist Agents of Change}

Similar to the male-led Islamic Movement, the female Islamist activists interviewed combine Islamist outreach with a focus on their Palestinian history and current predicament, as well as on the Arabic language. However, in addition to filling knowledge gaps produced by the Israel context, their focus is on educating women about their status and opportunities within Islam as perceived by the female Islamists, with the stated purpose of directly challenging what they see as the misunderstanding or purposeful misrepresentation of Islamic sources, which leads to the subjugation of women. In this way, they seek to empower Muslim women.

The new generation interviewees demonstrate agency, through their choices of education, and demonstrate freedom of opportunities, both through their ability to study topics of their choice at Israeli universities far from their families and communities and also through their choosing to be Islamist activists and wear the hija $\bar{b}$. Furthermore, they show agency through their aims and hopes for their future professional lives, which will most likely be challenged by their reality of being "trapped within a trapped minority", as well as by the limitations faced by most educated women who are also wives and mothers.

So whereas the young Islamist female students interviewed represent a new generation of activists who use their Islamic activism to critique and challenge patriarchal domination among Muslim Palestinian citizens of Israel, this challenge has its limitations. For example they support and practice gender segregation, including by refusing to allow female speakers to address mixed audiences. However, this analysis has suggested that this limitation has to be understood with a multilayered explanation based on the particular political and social context of these Palestinian citizens of Israel. By upholding the tradition of segregation, albeit in a new context and form, they are protesting the consequences of Israelization, in terms both of their political subjugation by the Israeli state as a national indigenous minority and of their cultural 
domination in the form of secularization due to assimilation. As such, keeping this tradition becomes the implementation through which they confirm and portray their cultural and religious authenticity and sincerity vis-à-vis the state and Israeli society, as well as vis-à-vis the secular national Palestinian political groups, which are assumed to be more Israelized. 